\title{
Chiang Kai-Shek
}

Introduction

General Overviews

Primary Sources

Archives

Collected Works and Books

Other Primary Sources

Collections of Visual Sources

Journals

Historiographical Overviews

Biographies

Upbringing and Early Career

Rise to Power and the "Chinese Revolution"

Nanjing Decade

Relationship with Japan

Second Sino-Japanese War

Civil War and "Loss" of the Mainland

Chiang Kai-shek on Taiwan

Cold War

Personality Cult, Commemoration, and Legacy

\section{Introduction}

Chiang Kai-shek (Jiang Jieshi 蔣介石)—also referred to as Chiang Chung-cheng (Jiang Zhongzheng 蔣 中正)-is one of the most controversial figures in modern Chinese history. He is also one of the most studied. He has been the focus of a vast array of historiography, biography, hagiography, and demonization. For early critics, Chiang was seen, from his purging of the Communists in 1927, as a "betrayer" of the Chinese Revolution. This assessment is now a point of considerable contention among historians. His creation of a unified yet authoritarian Chinese state during the Nanjing Decade (1927-1937) is also a prominent focus of scholarship, as is his role as China's leader during the Second Sino-Japanese War (1937-1945). Earlier assessments often ended their study of Chiang with his defeat by the communists in the Chinese Civil War and his subsequent flight to Taiwan in 1949. However, more recent scholarship has explored both the controversies and achievements of the quarter of a century that Chiang spent on Taiwan, and his legacy on that island in the period since 1975. There remain major differences in approaches to the study of Chiang along political, methodological, and national lines, but the deposition of Chiang's diaries at the Hoover Institution, Stanford University, in 2004 has ensured that a steady flow of 
scholarly reassessments has been published since then. This article focuses almost exclusively on studies of Chiang himself, rather than on studies dealing with immediate members of his family (such as Soong May-ling and Chiang Ching-kuo)—many of which would justify separate entries of their own.

\section{General Overviews}

Li 1986 and Huang 1994 provide two very different examples of Chiang studies favored in Taiwan in earlier decades: the former a highly provocative account, the latter a more orthodox historical analysis which provides a sympathetic reading of Chiang. Loh 1966 provides a balanced assessment which is still convincing, despite being superseded by diary-based scholarship in more recent years (see Historiographical Overviews). Lu 2011, Lu 2012, and Wang 2011 are useful collections of recent Chinese-language scholarship on Chiang emerging on both sides of the Taiwan Strait, while Yang 2008 is one of the most commonly cited examples of PRC-based scholarship on Chiang emerging since the opening of the Chiang diaries. Yamada and Matsushige $\underline{2013}$ is the most representative collection of recent Japanese scholarship on Chiang.

Huang Renyu 黃仁宇. Cong Dalishi de jiaodu du Jiang Jieshi riji(從大歷史的角度讀蔣介石日記). Taipei: Shibao wenhua chuban qiye youxian gongsi, 1994.

Covering the period between Chiang's time at the Whampoa Military Academy to the Second Sino-Japanese War, Huang (who himself served in Chiang's armies during the war) uses his well-known "macro-historical" approach to study the significance of Chiang in Republican Chinese history.

Li Ao 李敖. Jiang Jieshi yanjiu (蔣介石研究). Taipei: Tianyuan tushu youxian gongsi, 1986.

A deliberately provocative, quasi-scholarly assessment of Chiang by a public intellectual famous for his criticism of the KMT establishment on Taiwan under martial law. Originally banned in Taiwan.

Loh, Pichon. "The Politics of Chiang Kai-shek: A Reappraisal." Journal of Asian Studies 25.3 (1966): 431-451.

Loh wrote this "detached assessment of his [Chiang's] role in history" (p. 431) at the height of the Cold War, and it remains an important appraisal given that so few similar studies were attempted in this period. Loh presents Chiang as a "man with a compelling sense of public responsibility and an unquenchable thirst for personal power" (p. 451).

Lu Fangshang 呂芳上, ed. Jiang Zhongzheng riji yu minguo shi yanjiu (蔣中正日記與民國史研究). 2 vols. Taipei: Shijie datong chuban gongsi, 2011.

A representative collection of Chinese-language essays on various aspects of Chiang (and edited by one of the leading scholars in the field), all reflecting the move toward empirical diary-based scholarship occurring in the 2000 s. 
Lu Fangshang 吕芳上, ed. Jiang Jieshi de richang shenghuo (蒋介石的日常生活). Taipei: Zheng da chubanshe, 2012.

This collection originates in a major cross-Strait conference on Chiang held in Taipei. Unusually, it covers contributions on the less overtly political aspects of Chiang's life: his health, habits, and familial relationships, for example.

Wang Chaoguang 汪朝光, ed. Jiang Jieshi de renji wang/uo (蒋介石的人际网络). Beijing: Shehui kexue wenxian chubanshe, 2011.

An important instance of cross-Strait scholarly cooperation on Chiang-related scholarship (though tellingly, there were differences in the versions of this collection published in the PRC and, through China Times Publishing, in Taipei). Includes papers by almost all of the leading scholars working on Chiang in the Chinese-speaking world, the focus being Chiang's personality, morality, and behavior, including the nature of his relationships with those around him.

Yamada Tatsuo 山田辰雄 and Matsushige Mitsuhiro 松重充浩, eds. Shō Kaiseki kenkū: seiji, sensō, Nihon (蔣介石研究 : 政治· 戦争·日本). Tokyo: Tōhō shoten, 2013.

Edited by two leading Japan-based scholars of Chiang. Provides a thorough overview of the state of the field in the Japanese-speaking academy, with a significant number of contributions to the collection focusing (unsurprisingly) on Chiang's relationship with Japan.

Yang Tianshi 杨天石. Zhaoxun zhenshi de Jiang Jieshi: Jiang Jieshi riji jiedu (找寻真实的蒋介石: 蒋介石 日记解读). 2 vols. Hong Kong: Sanlian shudian, 2008.

Probably the most representative example of the highly empirical diary-based research on Chiang so common since the 2000s. Written by one of the PRC's leading exponents of such scholarship. Yang's analysis covers almost all periods and aspects of Chiang's political career between the Northern Expedition and 1949, but lays particular emphasis on issues that are of interest to PRC-based scholars, such as Chiang's relationship with the Chinese communists and his role in the Second Sino-Japanese War.

\section{Primary Sources}

Up until the 1990s, scholars were frustrated by a lack of access to primary sources related to Chiang, either due to the relative difficulty of accessing files in the PRC, or by the reluctance of the Nationalist Government on Taiwan to make available any sources which may have undermined Chiang's legacy. Scholars instead relied on officially published accounts in chronologies, collections of speeches, "collected works," and monographs published in Chiang's name. Greater access is now granted in most public 
institutions on both sides of the Taiwan Strait. Scholarship on Chiang underwent a fundamental change in 2004, when Chiang's diaries were first made available to researchers. While this has inspired new approaches and theories about Chiang, it has also led to many scholars moving away from other forms of primary source which once formed the basis of earlier scholarship. Memoirs by figures who lived or worked alongside Chiang have also contributed new, unofficial insights into Chiang's thinking, actions, and everyday life, though some of these accounts remain controversial.

\section{Archives}

Much of scholarship produced on Chiang Kai-shek since 2004 has made extensive use of Chiang's diaries (Jiang Zhongzheng riji). While these are an undoubtedly important source, there are also many other collections which remain crucial when undertaking research on Chiang Kai-shek, including the President Chiang Kai-shek Files at Academia Historica (Guoshiguan) and the KMT Party History Institute (Zhongguo guomindang dangshiguan), both in Taipei. In the PRC, the Second Historical Archives (Zhongguo di'er lishi dang'anguan) in Nanjing remain highly important.

Guoli Zhongzheng Jiniantang guanlichu 國立中正紀念堂管理處, Taipei.

The Chiang Kai-shek Memorial Hall holds the largest collection of hagiographical material relating to Chiang in the world, as well as important collections of ephemera and objects once belonging to Chiang. In addition, this institution has published a number of reference books on primary sources relating to Chiang available in Taiwan, and some important edited volumes (see *Chiang Kai-shek on Taiwan*)

\section{Guoshiguan 國史館. Taipei.}

Academia Historica holds the largest number of documents relating to Chiang Kai-shek's presidency of the Republic of China and earlier, the most relevant being the President Chiang Kai-shek Files (蔣中正總統文 物). Within this collection are the forty-seven-volume shilüe gaoben 事略稿本 (working manuscripts)—collections of speeches, telegrams, and reports from the Second Sino-Japanese War onwards.

Jiang Zhongzheng riji 蔣中正日記. Hoover Institution Archives. Stanford, CA.

Chiang's diaries, from 1917-1976 (some sections of which have been redacted or lost), are held at the Hoover Institution Archives, Stanford University, where they were deposited in 2004. According to Hoover, "Given the uninhibited nature of many personal comments in the diaries, family members have chosen to keep some passages private and have thus redacted these from the use copies." There are also on-going legal debates about ownership of the diaries. Some recent scholarship has questioned the overreliance on the diaries (see Historiographical Overviews), but they remain a crucial source., The full inventory to the 
Chiang Kai-shek diaries at Hoover is available *online*

[http://www.oac.cdlib.org/findaid/ark:/13030/kt438nc7np/]

Zhongguo di'er lishi dang'anguan 中国第二历史档案馆. Nanjing, China.

The Second Historical Archives was re-opened to researchers in 2015 after a period of some years, during which files were being digitized. Although many files which had been available to researchers prior to the digitization project are presently inaccessible, the Second Historical Archives nonetheless remains the most important site in the PRC for documents relating to Chiang's time on the mainland. Files relating to Chiang are spread across a range of different collections held here. The Archives have also published selections of documents relating to Chiang, as well as scholarship on Chiang undertaken by scholars based there.

Zhongguo guomindang dangshiguan 中國國民黨黨史館. Taipei.

This represents an invaluable collection of primary archival documents of diverse nature relating to Chiang and the party he led. Of particular import here are the Director General Chiang Kai-shek Archives (總裁檔 案). The catalogue of the Institute's archival holdings can be searched online. The Party Institute is currently working with the Hoover Institution Archives to make its collections available to researchers at Stanford.

\section{Collected Works and Books}

Many works penned in Chiang's name, such as Chiang 1947 and Chiang 1957, are now overlooked, but they remain relevant sources and provide a good understanding of the "official" voice that Chiang sought to present. Collections of Chiang's speeches and other writings were also produced at specific periods: Ministry of Information 1943 and Qin $\underline{1984}$ are good starting examples. Huang 2004 is a useful compilation of material relating to Chiang's period in Japan.

Chiang, Kai-shek. China's Destiny and Chinese Economic Theory. London: Dennis Dobson, 1947. Largely acknowledged to be ghostwritten by Tao Xisheng, the Chinese-language version of China's Destiny was produced in 1943 and presented to the world as Chiang's magnum opus, supposedly comparable in significance to Sun Yat-sen's Three Principles of the People. The overtly nationalistic sentiments present in the original Chinese version were diluted when the book was translated into English.

Chiang, Kai-shek. Soviet Russia in China: A Summing Up at Seventy. London: George G. Harrap, 1957. The showcase of Chiang's Cold War anti-communism (see Cold War), and a direct answer from Chiang to the question of why China was "lost" to the CCP in 1949 (see Civil War and "Loss" of the Mainland). 
Huang Zijin 黃自進, ed. Jiang Zhongzheng xiansheng dui Ri yanlun xuanji(蔣中正先生對日言論選集). Taipei: Zhongzheng wenjiao jijinhui, 2004.

A voluminous selection of documents detailing Chiang Kai-shek's views of Japan. Compiled from KMT and other archival sources (and with KMT funding), by one of Taiwan's leading historians of Chiang.

Ministry of Information, ed. The Voice of China: Speeches of Generalissimo and Madame Chiang Kai-Shek between December 71941 and October 10 1943. London: Hutchison, 1943.

A propaganda publication in which Chiang's wartime speeches were made available to readers in the Anglophone world.

Qin Xiaoyi 秦孝儀, ed. Zongtong Jiang Gong sixiang yanlun zongji (總統蔣公思想言論總集). 40 vols. Taipei: Zhongguo guomindang dangshi weiyuanhui, 1984.

The standard "collected works" compiled under the auspices of the KMT shortly after Chiang's death. A highly important yet underutilized source for the "official" position taken by Chiang on a range of issues across the decades.

\section{Other Primary Sources}

Chronologies of Chiang compiled by his courtiers, such as Ch'en 1993, provide the official narrative of Chiang's career. Recently, important work has also been done on recording and publishing oral histories or memoirs of individuals who were close to Chiang at different periods. Weng 1994 is one such example regarding Chiang's time on Taiwan, as is Ch'en 1993 with regards to Chiang's earlier life on the mainland, though the latter remains controversial.

Chen Bulei 陳布雷, ed. Jiang Jieshi xiansheng nianbiao (蔣介石先生年表). Taipei: Chuanji wenxue chubanshe, 1978.

This narrative chronology was compiled by one of Chiang's most trusted and long-serving aides (and ghostwriter). Provides the "authorized" account of the main events in Chiang's political career, compiled from the official record.

Ch'en Chieh-ju (Chen Jieru 陳潔如). Chiang Kai-shek's Secret Past: The Memoir of His Second Wife Ch'en Chieh-ju. Edited with an introduction by Lloyd E. Eastman. Boulder, CO: Westview, 1993.

This manuscript was first produced in the 1960s (ghostwritten by an acquaintance of Ch'en Chieh-ju (aka Jenny Chen)—supposedly Chiang Kai-shek's spouse from 1919 to 1927). Its publication was blocked by the KMT until after Chiang's death due to fears about the harm it might do to his reputation. The book remains controversial, and there are debates about the veracity of much of its content and even its authenticity. 
Weng Yuan 翁元. Wo zai Jiang Jieshi fuzi shenbian de rizi (我在蔣介石父子身邊的日子). Edited and compiled by Wang Feng 王丰. Taipei: Shuhua chubanshe, 1994.

The memoirs of Chiang Kai-shek's long-term bodyguard which provide an insight into Chiang's daily life, as well as insights into Chiang's private reactions to specific events throughout his career.

\section{Collections of Visual Sources}

Chiang Kai-shek was a highly visible figure throughout his political career. Wan 1994 provides a good starting point for official photography of Chiang on the mainland. Shi \& Yang 2005 represents a more popular collection. Enemy of the People: Visual Depictions of Chiang Kai-shek provides a wide range of "anti-Chiang" visual propaganda produced by Chiang's various detractors.

Enemy of the People: Visual Depictions of Chiang Kai-shek.

A database of approximately one hundred visual images of Chiang taken from a variety of sources and dating from the 1920s through to the 2000s. Hosted by the Humanities Research Institute at the University of Sheffield. Almost all images of Chiang in this collection are in some way negative or satirical.

Shi Yonggang 师永刚＆Yang Su 杨素, eds. Jiang Jieshi tuzhuan(蒋介石图传). Wuhan: Changjiang wenyi chubanshe, 2005.

A popular collection of images of Chiang drawn from a variety of news agencies and archival sources.

Wan Renyuan 萬仁元. Zhongguo jindai zhencang tupian ku: Jiang Jieshi yu guomin zhengfu (中國近代珍 藏圖片庫: 蔣介石與國民政府). 3 vols. Hong Kong: Shangwu yinshuguan, 1994.

A useful collection of hundreds of photographs held by the Second Historical Archives in Nanjing (see Archives). Provides photographic images of Chiang from the mid-1920s through to 1949. Usefully, many of the images are allowed to "speak for themselves."

\section{Journals}

There are no major journals specifically dedicated to the study of Chiang Kai-shek. However, the Journal of Modern Chinese History is the best English-language source of new scholarship on Chiang in the early 21st century, while Chinese Studies in History played a similar role in earlier decades. The Chinese Historical Review has published a special issue on Chiang arising out of diary-based scholarship. Minguo dang'an and Guoshiguan guankan regularly publish archive-based scholarship on Chiang, while Jindai Zhongguo and Jindaishi yanjiu both regularly publish academic studies from the Taiwan and the PRC, respectively.

The Chinese Historical Review. 1987-. 
This journal is affiliated with the Chinese Historians in the United States (under the American Historical Association). Although the journal is not focused purely on the study of Chiang Kai-shek, its March 2010 (17.1) issue included a series of responses from leading historians to Taylor $\underline{2009}$ (see Biographies). The journal also regularly publishes articles relevant to the study of Chiang.

\section{Chinese Studies in History. 1967-.}

This journal has been important in making works of Chinese-language historical scholarship accessible to the English-speaking academy. Its spring 1989 issue on the Xi'an Incident of 1936 (see Nanjing Decade) includes useful translations of accounts by eyewitnesses to this event.

\section{Guoshiguan guankan 國史館館刊. 1987-.}

Scholarship on Chiang produced by Taiwan-based scholars and arising out of the collections at Academia Historica is regularly published in this journal.

Jindai Zhongguo 近代中國. 1977-.

Originally affiliated with the KMT, this journal has become one of the leading outlets for Taiwan-based scholarship (often aimed at a lay as well as an academic readership) on Chiang since its founding.

Jindaishi yanjiu 近代史研究. 1979-.

Published by the Chinese Academy of Social Sciences, this journal has published a number of important contributions to the field by historians of Chiang Kai-shek based in the PRC since the 1990s.

\section{Journal of Modern Chinese History. 2007-.}

This journal publishes more scholarship on Chiang than any other periodical in the English-speaking world. It is particularly useful in providing English reviews of Chinese publications on Chiang, as well as access to recent scholarship on Chiang by scholars in the PRC.

Minguo dang'an 民国档案. 1984-.

Published by the Second Historical Archives (see Archives), this journal has been at the forefront of publishing revisionist scholarship on Chiang in the PRC, particularly that based on archival materials in China.

\section{Historiographical Overviews}

When read together, Alitto 1987, Huang 2011 and De Giorgi \& Samarini 2017 show how Western and Japanese scholarship has developed since the 1980s. Huang 2007 does the same for Chinese-language historiography. Lu \& Lin 2008 explores the wider significance of the opening of Chiang's diaries to historians (see Archives). 
Alitto, Guy. "Chiang Kai-shek in Western Historiography." In Proceedings of Conference on Chiang Kai-shek and Modern China. Vol. 1. 719-808. Taipei: China Culture Service, 1987.

A representative "state-of-the-field" piece appearing in an otherwise largely hagiographic collection of essays produced in late martial-law Taiwan. Alitto's study provides an accessible analysis of Cold War-era studies of Chiang in the English-speaking world.

De Giorgi, Laura and Guido Samarani (eds). Chiang Kai-shek and his Time: New Historical and Historiographical Perpectives. Venice: Edizioni Ca'Foscari, 2017

An interesting collection of essays on Chiang (and the historiography around him),this volume includes contributions from established historians of Chiang as well as younger scholars. The introduction provides a useful "state of the field" analysis.

Huang, Daoxuan. "Studies of Chiang Kai-shek by Mainland Scholars since the 1980s." Journal of Modern Chinese History 1.1 (August 2007): 81-95.

A highly accessible survey of Chiang-related scholarship produced in the PRC over recent decades. Huang details the main changes to assessments of Chiang which occurred prior to the surge in diary-inspired scholarship.

Huang, Ko-wu. "Retrospect and Prospect of Overseas Studies on Chiang Kai-shek and Related Topics." Journal of Modern Chinese History 5.2 (December 2011): 233-246.

This survey looks primarily at recent American (though also Japanese) studies of Chiang and possible directions for new studies in the field. There is a particular focus on the ways in which access to Chiang's diaries has influenced scholarship.

Lu Fang-shang and Lin Hsiao-ting. "Chiang Kai-shek's Diaries and Republican China: New Insights on the History of Modern China." The Chinese Historical Review 15.2 (January 2008): 331-339.

A balanced analysis of the significance of Chiang's diaries to the study of Chinese history, and the influence of the diaries on the study of Chiang more generally. Also tells the story of how the diaries came to be made available to scholars.

\section{Biographies}

Given the importance of Chiang in modern Chinese history, it is surprising that more scholarly biographies have not been written. Many of those that do exist are works of hagiography, as is the case with Tong $\underline{1938}$ and Furuya 1981, or demonization and criticism, of which Chen $\underline{1948}$ and Li 1986 (cited under General Overviews) are good examples. There have also been a number of popular biographies of Chiang written, including Croizier 1976 and Fenby 2003, which tend to focus on the theme of Chiang's "loss" of the mainland in 1949 (see also Civil War and "Loss" of the Mainland). Taylor 2009 is the most thorough 
academic biography of Chiang to be published in English; Yang $\underline{1989}$ is one of the most widely read biographies produced in the PRC.

Chen Boda 陈伯达. Renmin gongdi Jiang Jieshi (人民公敌蒋介石). Beijing: Renmin chubanshe, 1948. One of the most influential examples of communist denigration of Chiang. Penned during the latter stages of the Chinese Civil War. This tome would remain the template for many depictions of Chiang in the PRC well into the 1980s. Presents Chiang in the starkest of tones as an "enemy of the people."

Croizier, Brian. The Man Who Lost China: The First Full Biography of Chiang Kai-shek. London: Charles Scribner's, 1976.

The first biography to be published in English following Chiang Kai-shek's death. This is a popular rather than academic study. Written in the "great man" mode (without necessarily being hagiographic).

Fenby, Jonathan. Chiang Kai-shek and the China He Lost. London: Free Press, 2003.

A popular biography based mainly on secondary and English-language sources. As the title suggests, the book revisits the "loss of China" theme (see Civil War and "Loss" of the Mainland). Fenby's account ends in 1949.

Furuya, Keiji. Chiang Kai-shek: His Life and Times. Abridged English edition by Chun-ming Chang. New York: St John's University, 1981.

An officially commissioned biography which was commenced upon just prior to Chiang's death. Compiled by a team of Japanese journalists. This apologetic account devotes substantial coverage to specific episodes in Chiang's career on the mainland but little to the post-1949 period.

Taylor, Jay. Generalissimo: Chiang Kai-shek and the Struggle for Modern China. Cambridge, MA: Belknap, 2009.

The most comprehensive biography to be written in English. Includes a number of key revisions to earlier assessments about Chiang's marriage to Soong May-ling, his Christian faith, and his infamous relationship with Joseph Stillwell (see Second Sino-Japanese War). Based on diary material, archival sources, and oral testimonies. A Chinese translation was first published in Taipei by China Times Publishing (時報文化公司) in 2010.

Tong, Hollington K. Chiang Kai-shek: Soldier and Statesman. 2 vols. London: Hurst \& Blackett, 1938. The classic work of Chiang hagiography authored by one of Chiang's most loyal propagandists (and a former teacher at a school Chiang once attended). This tome was described by its author as "the life story of the Builder of New China who has successfully evolved order out of chaos. .." (p. v).

Yang Shubiao 杨树标. Jiang Jieshi zhuan (蒋介石传). Beijing: Tuanjie chubanshe, 1989. 
The first balanced biography of Chiang to be published in the PRC. It has been republished in subsequent editions, and is representative of the new wave of nuanced scholarship emerging from Zheijiang University (the only institution in China to host a research center dedicated to the study of Chiang) since the 1980s.

\section{Upbringing and Early Career}

The "official" narrative of Chiang's early life was produced in Mao 1965. Scholars have long explained Chiang's policies and actions with reference to his childhood and upbringing (e.g., Loh 1971). Such an approach has continued to shape recent scholarship in Chinese, such as that found in Wang, et al. 2012. Mainland organizations have compiled studies of Chiang's family background based on existing archival files, with one such example being Zhejiangsheng zhengxie wenshi ziliaohui weiyuanhui 1988. More recently, the period Chiang spent studying in Japan has been examined in works such as Huang 2001.

Huang Zijin 黃自進. Jiang Zhongzheng xiansheng liu-Ri xuexi shilu (蔣中正先生留日學習實錄). Taipei: Zhongzheng wenjiao jijinhui, 2001.

An authoritative and highly empirical account of Chiang's period in Japan as a student prior to the 1911 revolution by Taiwan's leading scholar on the topic.

Loh, Pichon P. Y. The Early Chiang Kai-shek: A Study of His Personality and Politics, 1887-1924. New York: Columbia University Press, 1971.

Loh's psychoanalytical study emphasizes Chiang's upbringing, and particularly his relationship with his parents, in explaining Chiang's activities during his early political career. This approach remains influential today, particularly in Chinese-language scholarship.

Mao Sicheng 毛思誠. Minguo shiwu nian yiqian zhi Jiang Jieshi xiansheng (民國十五年以前之蔣介石先生 ). Hong Kong: Longmen shudian, 1965.

Originally published in 1936. Mao Sicheng was a former teacher of Chiang's who was commissioned to produce this "official" account of Chiang's early life. Recently, access to new sources has suggested that Mao's account was a heavily edited one.

Wang Chaoguang 王朝光, Wang Qisheng 王奇生, and Jin Yilin 金以林, eds. Tianxia deshi: Jiang Jieshi de rensheng (天下得失: 蔣介石的人生). Taiyuan, China: Shanxi renmin chubanshe, 2012.

While not all chapters in this collection of recent work by PRC-based scholars focus on Chiang's early life, a recurring theme is that Chiang's conditioning during his childhood and youth influenced his later career and the decisions he made at key moments.

Zhejiangsheng zhengxie wenshi ziliaohui weiyuanhui 浙江省政协文史资料委员会, ed. Jiang Jieshi jiashi( 蒋介石家世). Hangzhou, China: Zhejiang renmin chubanshe, 1988. 
A useful guide to Chiang's family background compiled from the archival files held in Chiang's native Zhejiang province.

\section{Rise to Power and the "Chinese Revolution"}

There has been a good deal of scholarship on Chiang in the period between his appointment as head of the Whampoa Military Academy in 1924, and the foundation of the Nationalist Government in Nanjing in 1927. Chiang's role in the Northern Expedition was first explored in Isaacs 1951 in a highly negative fashion. This assessment was challenged in Jordan 1976. Scholarship undertaken with access to a variety of new sources, such as that found in Leutner, et al. 2002 and Tai $\underline{2009}$, has provided more nuanced interpretations of this period.

Isaacs, Harold R. The Tragedy of the Chinese Revolution. Stanford, CA: Stanford University Press, 1951. The source (through various editions) of the caricature of Chiang Kai-shek that held sway in much English-language scholarship from its first publication in 1938 through until the 1980s. Isaacs reportage presents Chiang as a servant of landlords and capitalists.

Jordan, Donald A. The Northern Expedition: China's National Revolution of 1926-1928. Honolulu: University of Hawai'i Press, 1976.

One of the most readable accounts of the Northern Expedition available in English. Jordan's study is important insofar as it was one of first monographs in English to challenge the Isaacs narrative. Jordan argues that China needed "the firm hand of a strong man" (p. 293) in this period.

Leutner, Mechthild, Roland Felber, A. M. Grigoriev, and M. L. Titarenko, eds. The Chinese Revolution in the 1920s: Between Triumph and Disaster. London: RoutledgeCurzon, 2002.

A highly significant and largely revisionist collection of papers focusing on the key period in 1926 and 1927. Tim Trampedach's chapter, for example, is an original contribution to the debate over Chiang's purge of the communists in 1927 and his commitment to the ideals of Chinese Republicanism.

Tai, Paul H. "Chiang Kai-shek's Rise to Power: Reflections from his Recently Released Diaries." American Journal of Chinese Studies 16.1 (April 2009): 49-63.

Tai uses the diaries at Stanford (see Jiang Zhongzheng riji, cited under Archives) to suggest that we need to look afresh at the reasons for Chiang's rise to political power in the 1920s. Central to Tai's argument (written in a highly sympathetic tone) is that Chiang's personality, and specifically his commitment to "self-improvement," needs to be considered when exploring his rise to power.

\section{Nanjing Decade}


There have been many debates around Chiang's activities during the period between 1927 and 1937 . Eastman 1974, Wakeman 1997, lechika 2002, and Huang 2011 all focus on the nature of Chiang's rule in this period, with the first two specifically examining the influence of fascism on Chiang's politics. Zanasi 2005 is important both in terms of its analysis of Chiang's economic policies and also for what it reveals about Chiang's relationship with Wang Jingwei. Chiang's rivalry with other KMT leaders is also analyzed in detail in Jin 2009. Specific events in this period have also been explored in some depth, including the Xi'an Incident of 1936, which finds in Wu 1976 its most comprehensive account. Duan 2006 is significant as a study of the New Life Movement which puts Chiang at the center of this campaign.

Duan Ruicong 段瑞聡. Shō kaiseki to shinseikatsu undo (蒋介石と新生活運動). Tokyo: Keiō gijuku daigaku shuppankai, 2006.

While studies of the New Life Movement are numerous, Duan's analysis puts Chiang Kai-shek at the center of this campaign. Duan argues that this movement reflected Chiang's approach to state-building, and was instrumental in the helping him consolidate power in the face of increasing pressure from Japan (see also Relationship with Japan).

Eastman, Lloyd E. The Abortive Revolution: China under Nationalist Rule, 1927-1937. Cambridge, MA: Harvard University Press, 1974.

One of the most oft-cited studies of Chiang's rule during the Nanjing Decade. Eastman famously suggested in this book that Chiang's talents ". . . were best suited to the old China. In the game of warlord politics, he was a master. But China was in the process of change, and the rules of the game of politics were changing accordingly" (p. 281).

Huang, Grace C. "Speaking to Posterity: Shame, Humiliation, and the Creation of Chiang Kai-shek's Nanjing Era Legacy." Twentieth Century China 36.2 (July 2011): 148-168.

Basing her analysis on the shilüe gaoben (see Guoshiguan, cited under Archives), Huang analyzes the ways in which Chiang Kai-shek and his secretaries utilized the concept of shame (chi) to justify his approach to specific events during the Nanjing Decade.

lechika Ryōko 家近亮子. Shō Kaiseki to Nankin kokumin seifu (蒋介石と南京国民政府). Tokyo: Keiō gijuku daigaku shuppankai, 2002.

A general history of the Nanjing Decade from a political science viewpoint. lechika locates the failure of Chiang's regime during this period in the KMT's lack of power and the party's lack of maturity in managing a party-based system of national politics. 
Jin Yilin 金以林. Guomindang gaoceng de paixi zhengzhi: Jiang Jieshi zuigao lingxiu diwei shi ruhe quelide (国民党高层的派系政治：蒋介石 “最高领袖” 地位是如何确立的). Beijing: Shehui kexue wenxian chubanshe, 2009.

A political history detailing Chiang's rise to power during the Nanjing Decade, with a focus on events in and around 1931. Jin argues that Chiang's rise had as much to do with internal divisions among his rivals as with Chiang's ability to make and break political allegiances.

Wakeman, Frederic, Jr. "A Revisionist View of the Nanjing Decade: Confucian Fascism." The China Quarterly 150 (June 1997): 395-432.

A key contribution to the debate about Chiang and fascism, and one written in direct response to Eastman 1974. Wakeman suggests that the "fascist" elements present in the political culture fostered around Chiang in this period were more complex than originally assumed.

Wu, Tian-wei. The Sian Incident: A Pivotal Point in Modern Chinese History. Ann Arbor: The University of Michigan Center for Chinese Studies, 1976.

The first scholarly monograph on Chiang's arrest in the city of Xi'an by Zhang Xueliang in December 1936 (the "Xi'an Incident") to be published in English. Wu argues that anti-Japanese sentiment (and anxieties over Chiang Kai-shek's apparent appeasement of Japan) in China at the time of the incident was genuine and widespread.

Zanasi, Margherita. Saving the Nation: Economic Modernity in Republican China. Chicago: University of Chicago Press, 2005.

An important contribution to our understanding of Chiang's view of the Chinese economy, based on extensive archival research in Nanjing, Shanghai, and Taipei. More importantly, this book provides an interesting insight into the roots of the wartime rivalry between Chiang and Wang Jingwei, and their conflicting views over China's road to modernization. Indeed, the book presents the Nationalist Government as "deeply divided" (p. 6).

\section{Relationship with Japan}

The relationship between Chiang Kai-shek and Japan, especially during the Nanjing Decade, has inspired a significant body of scholarship of its own. Jordan $\underline{2001}$ and So 2002 suggest that Chiang's attitude toward Japan in this period was far more resolute than previously assumed. Coble 1991 examines how Chiang's attitude to Japan had implications for his rivalry with the communists. Huang $\underline{2006}$ and Huang 2012 provide longer-term studies of Chiang's attitude toward Japan based largely on Japanese sources.

Coble, Parks M. Facing Japan: Chinese Politics and Japanese Imperialism, 1931-1937. Cambridge, MA: Harvard University Press, 1991. 
The authoritative account in English of Chiang's attempts to counter internal opposition during the Nanjing years while standing up to Japanese aggression in China.

Huang Zijin 黃自進, ed. Jiang Zhongzheng yu jindai Zhong-Ri guanxi (蔣中正與近代中日關係). 2 vols. Banqiao, Taiwan: Daoxiang, 2006.

This collection includes contributions from leading Chiang Kai-shek scholars based in Taiwan and Japan, and is the most thorough group of papers on all aspects of Chiang's relationship with Japan: The first volume contains only papers in Chinese; those in the second are all in Japanese.

Huang Zijin 黃自進. Jiang Jieshi yu Riben: yi bu jindai Zhong-Ri guanxi shi de suoying (蔣介石與日本 : 部近代中日關係史的縮影). Taipei: Zhongyang yanjiuyuan jindaisuo, 2012.

A highly detailed monograph which explores Chiang's lifelong relationship with Japan, from his time as a student in the country onwards.

Jordan, Donald A. China's Trial by Fire: The Shanghai War of 1932. Ann Arbor: University of Michigan Press, 2001.

Jordan's account of the often-forgotten 1932 "Shanghai War" is important, as it suggests the need for a fundamental reconsideration of Chiang's attitude toward Japan in the Nanjing years.

So, Wai Chor. "The Making of the Guomindang's Japan Policy, 1932-1937: The Roles of Chiang Kai-shek and Wang Jingwei." Modern China 28.2 (April 2002): 213-252.

An important contribution to the debate about Chiang Kai-shek's attitude toward Japan prior to the 1937 invasion. So argues that the Nationalist Government's supposed "appeasement" of Japan in this period was not purely a reflection of Chiang's anti-communism, but was equally the result of the input of other KMT leaders, most noticeably Wang Jingwei.

\section{Second Sino-Japanese War}

Chiang's role as wartime leader of China has emerged as a particularly rich vein of scholarship. Chiang's own official assessment of this period can be found in Chiang 1979. He 2011 provides a more up-to-date and detailed chronology of Chiang's activities during this period. The assessment of Chiang as a wartime

leader in Eastman 1984 is highly critical, and similar assessments can be found in Heiferman 2011. Other recent scholarship has been more nuanced: Chang 2007 examines the nature of Chiang's wartime leadership; Lin 2009 explores the influence of this conflict on Chiang's view of China's borderlands. Chiang's relationship with American military leaders such as Joseph Stillwell has been a particularly active debate, with the scholarship represented by Tuchman 1970 being challenged in van de Ven 2003. 
Chang, Rui-te. "Chiang Kai-shek's Coordination by Personal Directive." In China at War: Regions of China, 1937-45. Edited by Stephen R. Mackinnon, Diana Lary, and Ezra F. Vogel, 65-89. Stanford, CA: Stanford University Press, 2007.

An interesting examination of Chiang's methods of military management in the war against Japan. Chang suggests that Chiang's unusual and highly factionalized means of prosecuting the war worked against him.

Chiang, Wego W. K. How Generalissimo Chiang Kai-shek Won the Eight-Year Sino-Japanese War, 1937-1945. Taipei: Li Ming Enterprises, 1979.

The classic hagiographic account of Chiang's war against Japan written by Chiang's adopted son, Jiang Weiguo 蔣緯國.

Eastman, Lloyd E. Seeds of Destruction: Nationalist China in War and Revolution, 1937-1949. Stanford, CA: Stanford University Press, 1984.

A follow-up to Eastman's Abortive Revolution (see Nanjing Decade) detailing Nationalist failures during the wars against Japan and the communists. Eastman presents Chiang as a leader who was not fully aware of the plight of his own people during both the war against Japan and the conflict with the communists.

He Husheng 何虎生. Banian kangzhan zhong de Jiang Jieshi: 1937-1945 jishi(八年抗戰中的蔣介石: 1937-1945 紀實). Taipei: Fengyun shidai chubanshe, 2011.

A detailed chronology of Chiang's actions during the Second Sino-Japanese War. Covers virtually every aspect of this period, from Chiang's official visit to India to his deteriorating relationship with the United States.

Heiferman, Ronald lan. The Cairo Conference of 1943: Roosevelt, Churchill, Chiang Kai-shek, and Madame Chiang. Jefferson, NC: McFarland, 2011.

Heiferman's diplomatic history presents the Cairo Conference of November 1943 as a failure, and one in which Chiang's shifting demands of the United States and Britain in wartime set the tone for postwar tensions between the Nationalists and the Allies.

Lin, Hsiao-ting. "War, Leadership and Ethnopolitics: Chiang Kai-shek and China's Frontiers, 1941-1945." In Special Issue: Unlocking Modern Chinese History: New Discoveries from Chiang Kai-shek's Diary. Journal of Contemporary China 18.59 (2009): 201-217.

An example of diary-based scholarship which examines Chiang's role in shaping Nationalist Chinese wartime policies at China's peripheries. This was part of a special issue of the Journal of Contemporary China highlighting diary-related research on Chiang.

Tuchman, Barbara W. Sand against the Wind: Stillwell and the American Experience in China, 1911-45. London: Macmillan, 1970. 
The most thorough account in English of Chiang's relationship with the American general Joseph Stillwell during the war. Tuchman's damning assessment of Chiang set the tone for many subsequent studies of the topic.

van de Ven, Hans J. War and Nationalism in China, 1925-1945. London and New York: Routledge, 2003. An important contribution to the debate on the Chiang-Stillwell affair (and various other debates about war in the making of modern Chinese political culture more generally). van de Ven challenges many of the assumptions that had previously been made about Chiang's wartime relationship with the United States.

\section{Civil War and "Loss" of the Mainland}

Chiang's "loss" of mainland China in 1949 has been at the heart of much Chiang-related scholarship. Loh 1965 and Eastman 1981 suggest that the outcome of the conflict could be found in the corruption of the KMT, a view shared by Wang 2004, but challenged by Tanner 2015. Jiang and Liu 2013 also examines the military reasons for the outcome of the Civil War. Chiang's activities in and around 1949 have also become a key topic of debate, with a number of recent studies, such as Chen $\underline{2004}$ and Liu 2009, adopting more of a Taiwan-centric perspective. Lin 2016 explores the "accidental" nature of Chiang's ultimate retreat to Taiwan in 1949.

Chen Jinchang 陳錦昌. Jiang Zhongzheng qian Tai ji (蔣中正遷台記). Xindian, Taiwan: Xiangyang wenhua, 2004.

A consciously Taiwan-centric, but balanced, account of Chiang's loss of the Civil War and his subsequent flight to Taiwan. Published at the height of the pro-independence Chen Shui-bian 陳水扁 administration in Taipei. Provocatively, the author asks "If you believe that the current state of political division across the Taiwan Strait equates with Taiwan independence, then do you know who the first champion of the founding of Taiwan ( Taiwan jianguo) was?" (p. 232).

Eastman, Lloyd E. "Who Lost China? Chiang Kai-shek Testifies." The China Quarterly 88 (December 1981): 658-668.

A damning assessment of the "betrayal thesis" (i.e., the conviction among sections of the Nationalist elite that the United States had "sold out" the KMT in 1949). Eastman cites Chiang himself to suggest that the outcome of the Chinese Civil War had more to do with the KMT than with Chiang himself.

Jiang Yongjing 蒋永敬 and Liu Weikai 刘维开著. Jiang Jieshi yu guogong hezhan (蒋介石与国共和战). Taiyuan, China: Shanxi renmin chubanshe, 2013.

A military history of the Civil War which places the blame for the KMT's defeat in poor military planning rather than socioeconomic policies. The watershed moment for Jiang and Liu is the battle of Huaihai in 1948. 
Lin, Hsiao-ting. Accidental State: Chiang Kai-shek, the United States, and the Making of Taiwan. Cambridge, MA: Harvard University Press, 2016.

An important analysis of the processes leading to Chiang's retreat to Taiwan in 1949. Drawing on various archival collections, Lin argues that "...the accidental state on Taiwan, separate from the Chinese mainland, was the outcome of many ad hoc and unique factors, decisions, and even serendipity." (239)

Liu Weikai 劉維開. Jiang Zhongzheng de yijiusijiu: Cong xiaye dao fuxing shishi (蔣中正的一九四九 : 從下 野到復行視事). Taipei: Shiying chubanshe, 2009.

An account of the year in which Chiang's rule of the mainland ended, and an examination of how Chiang was able to reinvent himself. Written by a leading Taiwan-based scholar of Chiang and the Civil War.

Loh, Pinchon P. Y., ed. The Kuomintang Debacle of 1949: Collapse or Conquest? Boston: D.C. Heath, 1965.

A much-cited (if dated) volume which explores reasons for the KMT collapse of 1949. Includes a number of contributions on the role of China, as well as a chapter written by Chiang himself (in which he blames Soviet intervention and "KMT blunders" for the Communist victory on the mainland).

Tanner, Harold H. Where Chiang Kai-shek Lost China: The Liao-Shen Campaign, 1948. Bloomington, IN: Indiana University Press, 2015.

A response to earlier studies such as Eastman 1981. Tanner adopts a military history approach in examining the reasons for Chiang's "loss" of the mainland. He argues that ill-advised strategic decisions on Chiang's part were more crucial than PLA heroism in determining the outcome of the Civil War.

Wang Yinsuo 王颖硕. Jiang Jieshi baizou hei tudi (蒋介石败走黑土地). Beijing: Zhonggong dangshi chubanshe, 2004.

An overtly partisan (i.e., pro-communist) account of Chiang's loss to the CCP in the late 1940s. Focuses on China's northeast. This account is significant in going against the grain of more sympathetic analyses emerging in recent years.

\section{Chiang Kai-shek on Taiwan}

Contemporary assessments of Chiang Kai-shek's achievements on Taiwan after 1949 have been undertaken in a critical mode, such as Mancall 1964, and in a more supportive tone, such as Lumley 1976. Huang 2011 and Huang 2014 provide a series of chapters by leading historians from Taiwan on Chiang's political and military policies in the 1950s. Chen $\underline{2010}$ and Matsuda $\underline{2006}$ are two of the most comprehensive studies of Chiang's post-1949 career. One topic which remains controversial is Chiang's 
role in the events of early 1947 in Taiwan. This was first explored in Lai, et al. 1991, but was revisited in a more balanced way by Rawnsley and Rawnsley 2001.

Chen Hongmin 陈红民. Jiang Jieshi de hou bansheng: Jiangshu Jiang Jieshi Taiwan tongzhi suiyue (蒋介 石的后半生：讲述蒋介石台湾统治岁月). Hangzhou, China: Zhejiang daxue chubanshe, 2010.

A thorough study of Chiang's life on Taiwan. This account is unusual but also important in being one of the first nonpartisan accounts of Chiang's time on the island to be penned by a PRC-based historian. A representative example of the revisionist scholarship emerging from Zhejiang University.

Huang Kewu 黃克武, ed. Qian Tai chuqi de Jiang Zhongzheng (遷台初期的蔣中正). Taibei: Zhongzheng jiniantang, 2011.

A collection of essays by some of the leading scholars on Chiang in Taiwan, detailing Chiang's state-building, military, and policy efforts on Taiwan in the years immediately following 1949.

Huang Kewu 黃克武. Tong zhou gong ji: Jiang Zhongzheng yu yijiu wuling niandai de Taiwan (同舟共濟 : 蔣中正與一九五 $\bigcirc$ 年代的臺灣). Taibei: Zhongzheng jiniantang, 2014.

A follow up collection to Huang 2014, in which chapter authors (including leading Chiang scholars) examine Chiang's contributions to Taiwan through the 1950s from the perspective of politics, defense, and international relations.

Lai, Tse-han, Ramon H. Myers, and Wei Wou. A Tragic Beginning: The Taiwan Uprising of February 28, 1947. Stanford, CA: Stanford University Press, 1991.

The first and most comprehensive study of the "February 28th Incident" to be published in English, though still highly controversial. This book was criticized for absolving Chiang Kai-shek of any significant responsibility for the violence experienced on the island in early 1947.

Lumley, F. A. The Republic of China under Chiang Kai-shek Today. London: Barrie \& Jenkins, 1976. Might be read as a reply to Mancall 1964 . This work is highly apologetic about Chiang's record on Taiwan, stressing the rise in the standard of living which was experienced on the island in the 1960s and 1970s.

Mancall, Mark, ed. Formosa Today. New York: Praeger, 1964.

A selection of largely condemnatory articles detailing the nature Chiang's rule on Taiwan in the 1960s, and covering everything from foreign affairs to political opposition.

Matsuda Yasuhirō 松田康博. Taiwan ni okeru ichitō dokuritsu taisei no seiritsu(台湾における一党独裁体 制の成立). Tokyo: Keiō gijuku daigaku shuppankai, 2006. 
Explores the reasons behind Chiang's ability to recover his authority on Taiwan after the defeat of 1949. Covering areas such as Land Reform and reorganization of the KMT, the book provides a highly positive interpretation of Chiang's rule on Taiwan.

Rawnsley, Gary, and Ming-Yeh Rawnsley. "Chiang Kai-shek and the 28 February 1947 Incident: A Reassessment." Issues and Studies 37.6 (2001): 77-106.

A balanced analysis of an often-emotive topic. The authors explore the debate around Chiang's culpability for the infamous events of early 1947, but also respond to the account of this period provided by Lai, et al. 1991.

\section{Cold War}

Chiang's attempts to "recover the mainland" in the 1950s, and his role in the Offshore Islands Crises of that decade, have inspired studies such as Tsang 1993, with more recent scholarship, such as Yang 2014, suggesting that Chiang's commitment to such causes was indeed genuine. Koen 1974 remains the best-known account of Chiang's involvement in early Cold War politics in the United States via the China Lobby, while the influence of Chiang's regime on US foreign policy has been examined in detail by Chang 1990, Garver 1997, and Bush 2004. Tsang 2006 explores the pragmatic relationship that Chiang maintained with the United Kingdom in this period. Recent work, such as Gibson and Chen 2011, demonstrates how Chiang's influence in Southeast Asia was also significant in the Cold War.

Bush, Richard C. At Cross Purposes: U.S.-Taiwan Relations since 1942. Armonk, NY: M. E. Sharpe, 2004. Provides a detailed study of the role played by Chiang Kai-shek in the Republic of China's withdrawal from the United Nations under UN General Assembly Resolution 2758, which called for this body to "expel forthwith the representatives of Chiang Kai-shek from the place which they unlawfully occupy."

Chang, Gordon H. Friends and Enemies: The United States, China, and the Soviet Union, 1948-1972. Stanford, CA: Stanford University Press, 1990.

The most authoritative account in English of Chiang's involvement in wider Cold War politics. Based on both Chinese and foreign sources. Covers the Offshore Islands Crises of the 1950s and the eventual departure of Chiang's government from the United Nations.

Garver, John W. The Sino-American Alliance: Nationalist China and American Cold War Strategy in Asia. Armonk, NY: M. E. Sharpe, 1997.

Based largely on US archival sources. Explores the importance of Chiang's regime on Taiwan to US strategic aims in Asia and the wider world through until the 1970s. 
Gibson, Richard Michael, with Wen H. Chen. The Secret Army: Chiang Kai-shek and the Drug Warlords of the Golden Triangle. Singapore: John Wiley, 2011.

A "transnational" account of Chiang's role in supporting armed resistance to the PRC via KMT forces in Burma, Laos, and Thailand in the 1950s and 1960s. Details the complex relationship between Chiang's government in Taipei, the United States, Southeast Asian countries, and the narcotics trade at the time.

Koen, Ross Y. The China Lobby in American Politics. Edited with an introduction by Richard C. Kagan. New York: Harper \& Row, 1974.

A well-known though controversial work which was originally intended to be published in 1960. Remains the most important and detailed study of attempts by the Nationalists under Chiang Kai-shek to influence internal US politics in the late 1940s and early 1950 s.

Tsang, Steve. "Chiang Kai-shek and the Kuomintang's Policy to Reconquer the Chinese Mainland, 1949-1958." In In the Shadow of China: Political Developments in Taiwan since 1949. Edited by Steve Tsang. London: C. Hurst, 1993.

An important contribution to the scholarship on Chiang's mindset in the 1950s, and how his attitude toward the mainland shaped both domestic and external policies in this period.

Tsang, Steve. The Cold War's Odd Couple: The Unintended Partnership between the Republic of China and the UK, 1950-58. New York: I. B. Tauris, 2006.

A diplomatic history of the relations between Britain and Chiang Kai-shek's Taiwan in the context of the Offshore Islands Crises of the 1950s. Tsang argues that "the fact that he [i.e., Chiang] realized he had no realistic chance of retaking the mainland did not mean that he had given up the hope or emotional commitment to do so" (p. 192).

Yang, Huei Pang. “Taiwan and Chiang Kai-shek's fangong Dalu.” Asian Affairs 45.1 (2014): 79-107. Yang's is one of the few studies in English to take Chiang Kai-shek's hypothetical plan to "retake the mainland" following 1949 seriously. As Yang shows, Chiang's desire to one day reclaim mainland China was the cause of significant tension between Taiwan and the United States throughout the Cold War.

\section{Personality Cult, Commemoration, and Legacy}

While often overlooked in the past, the ways in which Chiang is now remembered, and his legacy assessed, represent an increasingly important focus of recent scholarship. Corcuff 1997 was one of the first studies of changes to public memory of Chiang in Taiwan to be published, though Taylor 2010, Matten 2012, and Musgrove 2017 continue to analyze such trends. Wakeman 1996 offers an interesting analysis of Chiang's funeral in Taipei in 1975, while Taylor 2006 looks at this cult during Chiang's lifetime. 
Corcuff, Stéphane. "Que reste-t-il de Chiang Kai-shek? Ritualisation d'une commémoration politique à Taiwan (1988-1997)." Études chinoises 16.2 (automne 1997): 115-146.

An important examination of the ways in which praise for Chiang was "ritualized" in Taiwan under the leadership of Lee Teng-hui. Corcuff was one of the first scholars to address changes to the public memory of Chiang in Taiwan in the 1990s.

Matten, Marc Andre. "The Chiang Kai-shek Memorial Hall in Taipei: A Contested Place of Memory." In Places of Memory in Modern China: History, Politics and Identity. Edited by Marc Andre Matten, 51-90. Leiden, The Netherlands: Brill, 2012.

Matten is a good starting point for a growing body of scholarship on the Chiang Kai-shek Memorial Hall in Taipei, and debates about the site's significance in the early years of the 21 st century.

Musgrove, Charles. "Taking back space: The Chiang Kai-shek Memorial Hall and Taiwan's Democratization." Twentieth Century China 42.3 (2017): 297-316.

The most up to date discussion of the multiple meanings that have been attached to the Chiang Kai-shek Memorial Hall in Taipei since its construction, this paper builds on ideas and debates first explored in Matten 2012.

Taylor, Jeremy E. "The Production of the Chiang Kai-shek Personality Cult, 1929-1975." The China Quarterly 185 (2006): 96-110.

Explores how artists, writers, and propagandists both on the mainland and on Taiwan played a role in creating a Chiang Kai-shek personality cult, rather than having it forced upon them.

Taylor, Jeremy E. "Qujianghua: Disposing of and Re-appraising the Remnants of Chiang Kai-shek's Reign on Taiwan." Journal of Contemporary History 45.1 (2010): 181-196.

An examination of the attempts to "de-Chiang Kai-shek-ify" Taiwan during the Chen Shui-bian years (2000-2008). Taylor suggests that efforts to remove Chiang from public discourse in Taiwan inadvertently restarted a previously moribund debate about Chiang's significance to the history of the island.

Wakeman, Frederic, Jr. "Revolutionary Rites: The Remains of Chiang Kai-shek and Mao-Tse-tung." Representations 10 (Spring 1985): 146-193.

A comparative study of the state funerals of Chiang Kai-shek and Mao Zedong. Wakeman's was important in bringing Chiang Kai-shek back into studies of the commemoration of "great men" in China (which had hitherto been dominated by the figure of Mao) but also in locating continuities between PRC and KMT rituals of mourning for their respective leaders. 